\title{
RESEARCH EXPENDITURE IN THE PHARMACEUTICAL INDUSTRY
}

$\mathrm{R}$ ESEARCH expenditure by the pharmaceutical industry in Britain has been levelling off, after rising rapidly between 1955 and 1960 . The Association of the British Pharmaceutical Industry's latest survey of research expenditure by its members shows that, in the year 1961-62, approximately $£ 7.8$ million was spent in the search for and the development of new medicines, together with $£ 0.8$ million paid for research carried out overseas. This represents only a slight increase over the previous year, when expenditure in Britain amounted to $£ 7.5$ million. In the previous five years, the industry had more than doubled its expenditure on research. Forecasts based on past trends and on experience of other countries had estimated that research expenditure would have reached an annual rate of between $£ 9$ million and $£ 10$ million by the end of 1962 .

Dr. D. E. Wheeler, the president of the Association of the British Pharmaceutical Industry, has shown that the research effort of the industry is by any standards a large one. It represents about one-third of all medical research in Britain. The British industry hed set its sights high, however, and this slowing down of the rate of expansion of research in Britain is disappointing.

The industry had given in the past many warnings that the continued pressures to which it has been subjected must eventually affect adversely its research programmes. Important factors have been the weakening of patent protection, the undermining of the use of brand names, and pressures on prices leading to uncertainties about the industry's future. Article $\mathbf{4 6}$ of the Patents Act, for example, has been used to authorize the import of cheap drugs from abroad, the manufacturers of which have not always borne the costs of discovering, and developing them for clinical use, and who frequently do not hold the original patent rights on them. It has also been Government policy to discourage the prescribing of branded pharmaceuticals. A brand name is essential if a firm is to secure continuity of sales so that its investment in research has a reasonable chance of being rewarded.

Research in the pharmaceutical business carries a high risk for the entrepreneur, and excessive pressure on prices must tend to discourage investment in research. In the home market, prices are closely limited by the Voluntary Price Regulation Scheme negotiated between the industry and the Ministry of Health, and there is danger of leaving too little room for financing research.

On the export side, the industry exports about cnequarter of its output and contributes more than $\$ 50$ million to Britain's export earnings. It also brings in substantial foreign exchange through subsidiaries abroad and from licences to manufacture products developed in Britain. The greater part of this trade is in branded medicines, but, with inereasingly intense international competition, profit margins are diminishing and manufacturers have found that they cannot look to export markets for major support of their research programmes.

Copies of the survey are obtainable from the Association of British Pharmaceutical Industry, South Wing, B.M.A. House, Tavistock Square, London, W.C.1.

\section{DIELECTRIC CONSTANT RELAXATION TIME SHIFT IN AN ELECTRIC FIELD}

\author{
By CR. J. B. HASTED, M. A. SHAH and P. R. MASON \\ University College, London, and Laboratories R.C.A., Ltd., Zurich
}

\begin{abstract}
7 HIS article describes a change in the complex dielectric constant of nitrobenzene at $3 \cdot 33-\mathrm{cm}$ wavelength, $20^{\circ} \mathrm{C}$ temperature, when an intense steady electric field is applied. The change is consistent with a decrease in the single relaxation time of the dielectric constant; the increase in static dielectric constant ${ }^{1}$ must be taken into account. Following some preliminary free-wave experiments with uniform electric field on $\gamma$-picoline and nitrobenzene by one of us (P.R.M.), it was decided to search for complex dielectric constant change in nitrobenzene of high purity contained between $0 \cdot 228$-in. polythene windows $P$ in a rectangular $\mathrm{H}_{01}$ size 16 wave-guide cell; two $0 \cdot 0028$-in. tungsten wires $W, 3 \mathrm{~mm}$ apart, were stretched between the windows, parallel with the waveguide axis, as in the inset to Fig. 1 . The wires were passed through insulators $I$ in opposite short sides of the waveguide; tubes $T$ for filling the cell were soldered on opposite long sides of the wave-guide. The cell was connected in a bridge circuit ${ }^{2}$ which facilitated the measurement of phase change and attenuation of the guided wave on passing through the cell.

The application of steady potential differences $V$, up to $3,000 \mathrm{~V}$, between the wires produced no observable effect on the microwave properties of the empty cell, due, for example, to Coulomb attraction between the wires. However, a small change of phase and attenuation was produced by the application of a steady potential between the wires of a cell containing high-purity nitrobenzene. Great care was taken with the filling of the cell, which was
\end{abstract}

carried out under vacuum to avoid bubbles. The time constant of the measuring system, o phase-sensitive tuned amplifier, was sufficiently small to make it reasonably certain that any long-term microwave changes due to Joule heating by the steady e.m.f. could be eliminated.

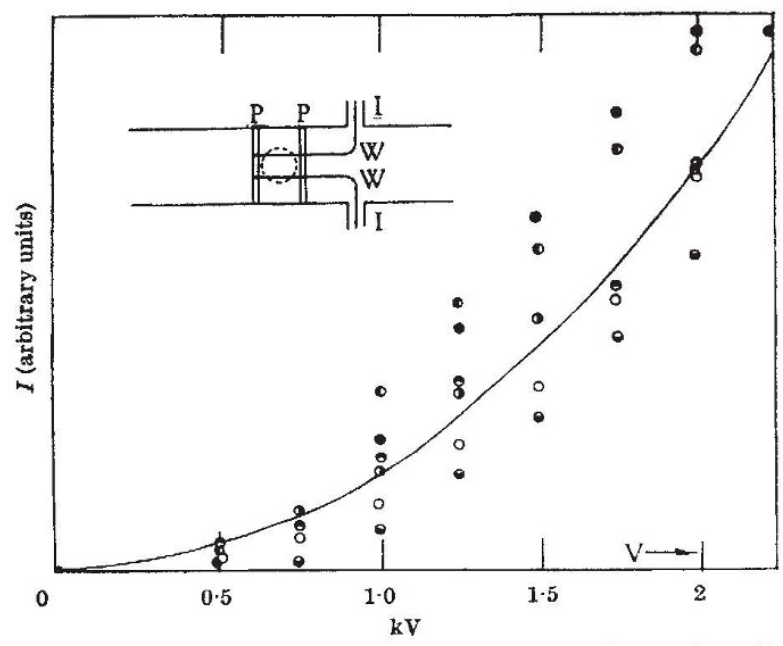

Fig. 1. Variation of response, previously set to minimum, $I_{m}$, with steady potertial difference. Inset shows wave-guide cell, not to scale, viewed with the $E$ vector orthogonal to the paper 